一般手術における輸血削減への取り組み一周術期のPatient Blood Management を考える一 希釈式自己血輸血による同種血輸血回避の努力 北山眞任 ${ }^{* 1}$ 齋藤淳一 ${ }^{* 2}$ 廣田和美 ${ }^{* 2}$

[要旨］自己血輸血は同種血輸血に伴う感染症・免疫性副作用を回避しうる最も良質な輸血療法で ある. 希釈式自己血輸血 (hemodilutional autologous blood transfusion ; 以下HAT)は貯血式 や回収式に比べ術前の準備を要さず血小板・凝固機能が維持され, 悪性腫瘍・感染症例でも施行可 能な利点を有し, さらにろつの方法を組み合わせることにより輸血回避の幅が増加する. 当院で は 1990年代以降, 麻酔科が中心となり積極的にHATを施行し, 出血量2,000g以下の87\%以上, 2,000 3,000g の出血でも 40\%前後で同種血輸血が回避されている. 近年, 同種血輸血は安 全性が劇的に向上している一方, 大量輸血による輸血関連急性肺障害はいまだ致死率が高く, 腫瘍 免疫低下による再発予後への影響は否定されていない. 今後, 手術の低侵襲化や止血環境の向上に 伴い, 輸血治療もHATを含む自己血輸血が患者の予後を改善する大きな役割を担うと予想される. キーワード：希勫式自己血輸血，同種血輸血，輸血合併症

はじめに

希釈式自己血輸血(hemodilutional autologous blood transfusion；以下HAT)は，貯血式自己血輸血や回 収式自己血輸血とともに同種血輸血に伴う感染症, 免疫性副作用を回避しうる最も良質な輸血治療であ る。当施設では 1990 年代から現在まで整形外科, 婦人科を中心に大量出血が予想される侵襲の大きな 手術患者の麻酔計画で積極的にHATを選択し，同 種血輸血の回避に努めてきた。その一方で献血検体 検査の精度向上により輸血後感染症の発症は激減 し，管理に労力を要する自己血輸血の意義が問われ ることもある。また近年, 腹腔鏡手術やロボット手 術など手術様式の変化により術中の出血が減少傾向 にある。
2016年の診療報酬改定により，貯血式自己血輸 血, 回収式自己血輸血に続いてHATが初めて保険 収載された。そこで本稿では当施設における HAT の推移を紹介するとともに，改めてその有効性と可 能性について紹介したい.

\section{I 自己血輸血の分類}

自己血輸血には，貯血式，希釈式，回収式の $3 つ$ の方法がある。

(1)貯血式自己血輸血

手術前に $2 \sim 3$ 回に分けて採血を行う。さらに保 存方法により, 以下に分類される。 i ) 全血として そのまま $4 \sim 6^{\circ} \mathrm{C}$ で冷蔵保存(保存液として CPDを 使用する場合には21日間，CPDA-1を使用する場 合には35日間保存可能), ii ) 赤血球と血漿に分離 
表 1 自己血輸血の種類と特徵

\begin{tabular}{|c|c|c|c|}
\hline & 貯血式 & 希釈式 & 回収式 \\
\hline 概要 & $\begin{array}{l}\text { • 計画的に採血 } \\
\text { • 保存と繰り返し採血 }\end{array}$ & - 当日開始前に採血 & $\begin{array}{l}\text { • 術野 / ドレーンから回収 } \\
\text { •濃縮と洗浄処理 }\end{array}$ \\
\hline 長所 & - 最大 $6-8$ 単位可能 & $\begin{array}{l}\text { ·凝固因子が確保 } \\
\text { ・血小板の補充可能 } \\
\text { ・希釈により赤血球喪失 } \\
\text { 量が削減 }\end{array}$ & $\begin{array}{l}\text { · 大量出血に対応 } \\
\text { ·緊急使用可能 }\end{array}$ \\
\hline 短所 & $\begin{array}{l}\text { • 緊急手術には不可 } \\
\text { • 保存中にサイトカイン } \\
\Rightarrow \text { 副反応の可能性 }\end{array}$ & • 採血量に制限 & $\begin{array}{l}\text { • 細菌・脂肪による污染 } \\
\text { • 術野の感染あるいは } \\
\text { 悪性腫瘍手術は禁忌 } \\
\text { • 赤血球成分のみ回収 }\end{array}$ \\
\hline
\end{tabular}

し, 赤血球はMAP液を加えて冷蔵保存(42日間保 存可能), 血漿は新鮮凍結血漿(FFP) として冷凍保 存， iii )FFP と同様に赤血球もグリセリン液を添加 し冷凍保存 (10 年間)。採血は原則として 1 週間以上 の間隔をあけて行い, 貯血量や患者 $\mathrm{Hb}$ 值に応じて エリスロポエチン製剤の投与を行う。 3〜 4週前か ら最大 $1,200 \sim 1,600 \mathrm{~mL}$ の準備が可能であるが，貧 血が進行する場合は必要な血液量を確保できないこ ともある。 また，全血保存されている製剤内の白血 球が分泌するサイトカインなどの生理活性物質が原 因と考えられる発熱や悪寒などの副反応も報告され る。しかし全血冷蔵保存法は特別な器具や装置を必 要としないので広く普及している。

(2) 回収式自己血輸血

心臓血管外科手術のように大量出血が予想される 手術では, 出血を吸引によって回収し遠心分離器で 赤血球だけを回収し返血する洗浄式自己血回収シス テムによる術中回収法が有効である。人工膝関節手 術のような主に術後に出血する手術では回収した全 血をフィルターを通して戻す術後回収法がある。た だし回収した血液には細菌や脂肪が混じる危険性が ある。同様にがんの手術では術野からがん細胞が回 収血に混入する危険性が高く禁忌である。

(3) 希勫式自己血輸血(HAT)

血液バッグとローラーペンチ・シーラー以外に特
別な器具を必要としない. 貧血が強い場合や循環動 態が安定しない状況を除いては緊急手術でも可能で ある。手術直前に採血する本法の血液製剤は新鮮血 であり止血に機能しうる血小板や凝固因子を含んで いる。.さらに採血量に応じた膠質液の補充による希 釈を行うことで実質的出血量 (=赤血球喪失量)を軽 減できる。ただし採血の機会は手術直前の 1 回だけ であり，貯血式と異なり採血量に限界がある。

以上の 3 つの方法の特徵および長短を表 1 に示し た.

\section{II 同種血輸血の合併症と自己血輸血の利点}

\section{1. 輸血後感染症のリスク}

近年，同種血輸血による輸血後感染症のリスクは 減少しており, 特に 2014 年に輸血検体の HBV, HCV およびHIV 感染に対する核酸増幅検査に個別検体 によるNAT法が導入されてから，感染初期のウイ ンドウ期をすり抜けた感染は 2015〜2017年に HBV 2例， HCV，HIVは0例と激減した。その結果，推 定年間輸血後感染数は, HBV は 160 万本の輸血に 1 件(年間 3.1 件), HCV, HIV 感染リスクは推定困難 なレベルまで低下している ${ }^{1)}$ 。しかし2007〜2009 年では，本邦における献血者自体の HIV 感染陽性 者数は約 100 件を超えており，現在(2017年)では約 半数に減少したが，検査のすり抜けを生ずる危険性 
は大きい. 個別NAT法でもウインドウ期は約 6 週 間であり感染リスクを完全になくすことは困難であ る.

ウイルス感染以外にも同種血輸血では溶血性副作 用(急性, 遅発性), アナフィラキシー反応を含むア レルギー反応, 輸血関連急性肺障害(TRALI), 輸 血関連循環過負荷 (TACO), 輸血後移植片対宿主病 (GVHD), および輸血による免疫修飾(TRIM)など の重篤な副作用を生じうる ${ }^{2), 3)}$. TRALI は輸血後6 時間以内に生じる非心源性肺水腫と定義され, 致死 率は約 $10 \%$ と高い. 抗白血球抗体と白血球の抗原 抗体反応が補体を活性化し，好中球による肺毛細血 管内皮細胞の障害と考えられているが，HATを含 め自己血輸血では免疫反応を介する副作用の可能性 は極めて低い.

\section{2. 担がん患者の免疫機能への影響}

HATは1974年にMessmerらによって初めて臨 床例が報告されたが ${ }^{4)}$ ，この時期に外科領域ではが ん手術後の同種血輸血による再発率への影響が示唆 され始めた。すなわち輸血によりヒトの抗腫瘍性反 応が抑制され, その結果, 腫瘍の増殖が促進され再 発や転移を起こしやすい，悪い影響を与えるという 仮説を提言する研究がいくつか報告されている ${ }^{5), 6)}$. Francisらの研究では, 輸血とがんに関する当時の 論文 72 編のうち各臓器がんにおいて輸血ががんの 予後を悪くしているという結論を示した報告は 45 $\%$ に及んでいる ${ }^{5)}$. 現在もなお，基礎研究も含め周 術期の輸血による細胞性免疫, 液性免疫を介する免 疫抑制の明確なメカニズムは不明であるが，現象と しての同種血輸血によるがん術後患者の生存率低下 は否定されていない. 2006 年のCochrane review では赤血球輸血と結腸手術術後予後における中等度 の関連性が示されている (odd ratio=1.42). さらに

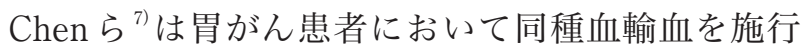
された群と自己血輸血を施行された群との間で $\mathrm{IFN}-\gamma, \mathrm{T}$ リンパ球サブセット $(\mathrm{CD} 3+, \mathrm{CD} 4+$, $\mathrm{CD} 8+, \mathrm{CD} 4+/ \mathrm{CD} 8+)$ を測定し術後免疫抑制の
程度を比較し, 同種血輸血を施行された群で自己血 輸血群に比べ免疫抑制程度が大きいことが示されて いる.

Hiller $ら^{8)}$ は，手術操作による腫瘍細胞の拡散以 外に“全身麻酔”, “輸血”, “低体温”および “モ ルヒネを中心としたオピオイド”など周術期に不可 欠な治療の中にも腫瘍細胞や細胞性免疫能に影響を 及ぼし予後を悪化させるものがあることを示唆して おり, 結論は出ていないものの, 同種血輸血の回避 を含めて繊細な麻酔管理が患者の予後を改善するの は間違いないと考える。

\section{III 当院での希釈式自己血輸血による 同種血輸血回避状況}

\section{1. 当院でHAT が普及した背景}

前述の経緯を踏まえ当院麻酔科では，1989年以 降，術後患者の免疫能の低下を避けるため, “がん の患者では輸血をぎりぎりまで粘る”管理が麻酔科 全体で徹底され，HATはその一環として頻繁に選 択されるようになった。当院における初めてのHAT 症例は，Messmer らの報告からわずか 6 年後の 1980 年 5 月に整形外科の腸骨骨腫瘍摘出術に対し行われ た。 その後, 術者と麻酔科で適応を協議し, 十分に 安全が確保しうる患者に散発的に施行されていた が，1988年術中回収式自己血輸血，1990年貯血式 自己血輸血，および1993年に貯血式でエリスロポ エチンの使用が相次いで保険収載され，当院で自己 血輸血への関心が高まった。そこで麻酤科が中心と なってHAT施行を手術関連の診療科に積極的に働 きかけ，病院全体による組織的な運用が婦人科悪性 腫瘍手術や整形外科手術から開始された。さらに輸 血部の協力のもと前立腺全摘手術では貯血式を併用 し，ほとんどの症例で同種血輸血が回避されている $(2010 \text { 年度の実績で約 } 98 \%)^{9)}$ 。 また人工股関節置換 術，股関節回転骨切術，脊椎手術や心臓血管外科の 開心手術(小児例を含む) は回収式自己血輸血との併 用が常時行われるようになった。2000年代以降は, 


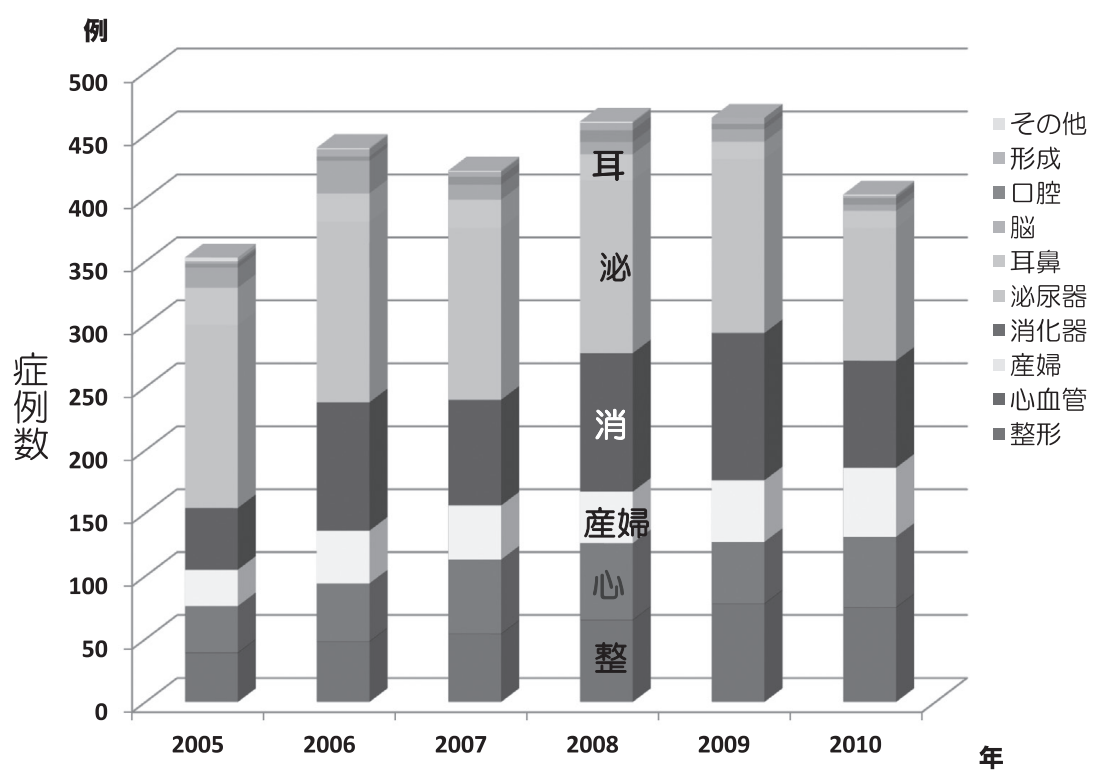

図 1 診療科別: HAT 症例数の推移 (2005年〜 2010年)

生体肝移植術ドナーを含む肝切除術, 膵頭十二指腸 切除術, 耳鼻科や口腔外科の頸部廓清を伴う頭頸部 悪性腫瘍手術などで麻酔科への HAT申し込みが増 加した. 2005〜2010年の年次HAT症例数の推移 を図1に示す。この 6 年間は $300 ４ 50$ 件/年 (2008 年は麻酔科管理症例の約 $13 \%)$ と施行症例数がピー クに達し, 麻酔科だけではなく各診療科の主治医に も同種血輸血による予後への意識が浸透したと思わ れる。

\section{2. 同種血輸血回避の実際}

ピーク時である2008年に施行されたHAT症例は 計 461 例であり, 採血量は $400 \mathrm{~g}$ 未満(採血量 $200 \mathrm{~g}$ ま たは $300 \mathrm{~g}$ )が 4 例, $400 \sim 800 \mathrm{~g}$ 未満(採血量 $400 \mathrm{~g}$ また は $600 \mathrm{~g}$ ) が81 例, $800 〜 1,200 \mathrm{~g}$ 未満(採血量 $800 \mathrm{~g}$ また は 1,000g) 364例, 1,200〜 1,600g 未満(採血量 1,200g, $1,400 \mathrm{~g}) 11$ 例, $1,600 \mathrm{~g}$ が 1 例であった。 $400 \mathrm{~g}$ 未満は 学童小児症例, $1,400 \mathrm{~g}$ 以上の挑戦的な採血量は, 宗 教的理由により同種血輸血を拒否した患者や壮健な 悪性腫瘍患者に限定された。出血量別の同種血輸血 回避状況を図2に示す。1,000 $\mathrm{g}$ 以下の出血量では術 中の回避率は約 $99 \%$ (術後使用を含め $95 \%$ ), 1,000 〜2,000g では回避率約 $99 \%$ (同 $87 \%$ ) であり，まと めて出血量 $2,000 \mathrm{~g}$ 以下でも術後使用を含め $87 \%$ 以上 の回避率であった。採血量別では，400〜 1,200g未 満 $(400,600,800$ および $1,000 \mathrm{~g})$ で $95 \%$ の回避率で あった(図3)。

\section{3. 手術環境の変化と現在の HAT施行状況}

2008 年以降, 当院の HAT施行数は減少し, 2017 年は約 270 件/年とピーク時の $62 \%$ に減少した。要 因として，この期間に内視鏡手術やロボット支援手 術の普及により各診療科の手術内容が変化したこと が挙げられる. 新しい術式の実際の出血量が減少し, 最大手術血液準備量 (MSBOS) や手術血液準備量計 算法 $(\mathrm{SBOE})$ などから導かれる輸血準備量が 1 〜 単位である場合, 輸血治療自体の必要性が低下する。 例えば前立腺がん手術では，2008年では鏡視下小 切開前立腺全摘術が中心であったが，2012年以降， ロボット支援手術(ダ・ヴィンチ)が導入され平均出 血量は減少した。進行度の低い腎蔵がんや生体腎移 植ドナーの腎摘出術において腹腔鏡手術が主流とな り, 泌尿器科手術全体で, 2008年度に比べHAT適 応症例は約 100 件減少 $(-70 \%)$ している(図4). 


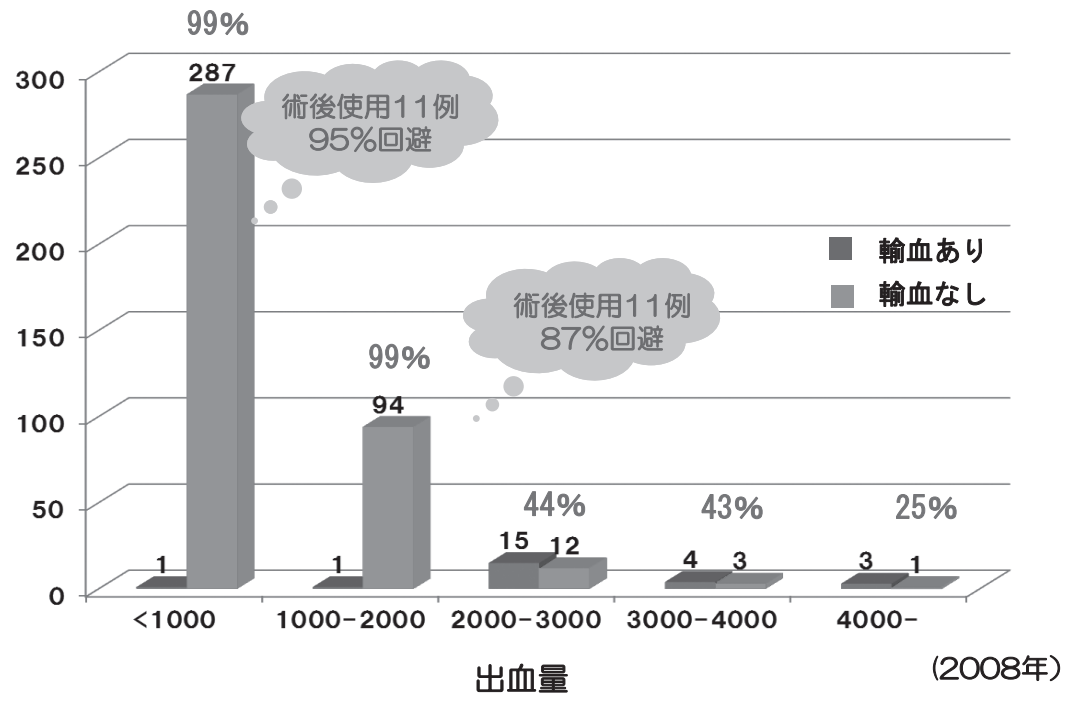

出血量2000g以下で, 術後を含め87\%以上回避

図2 同種血輸血の回避状況：出血量別

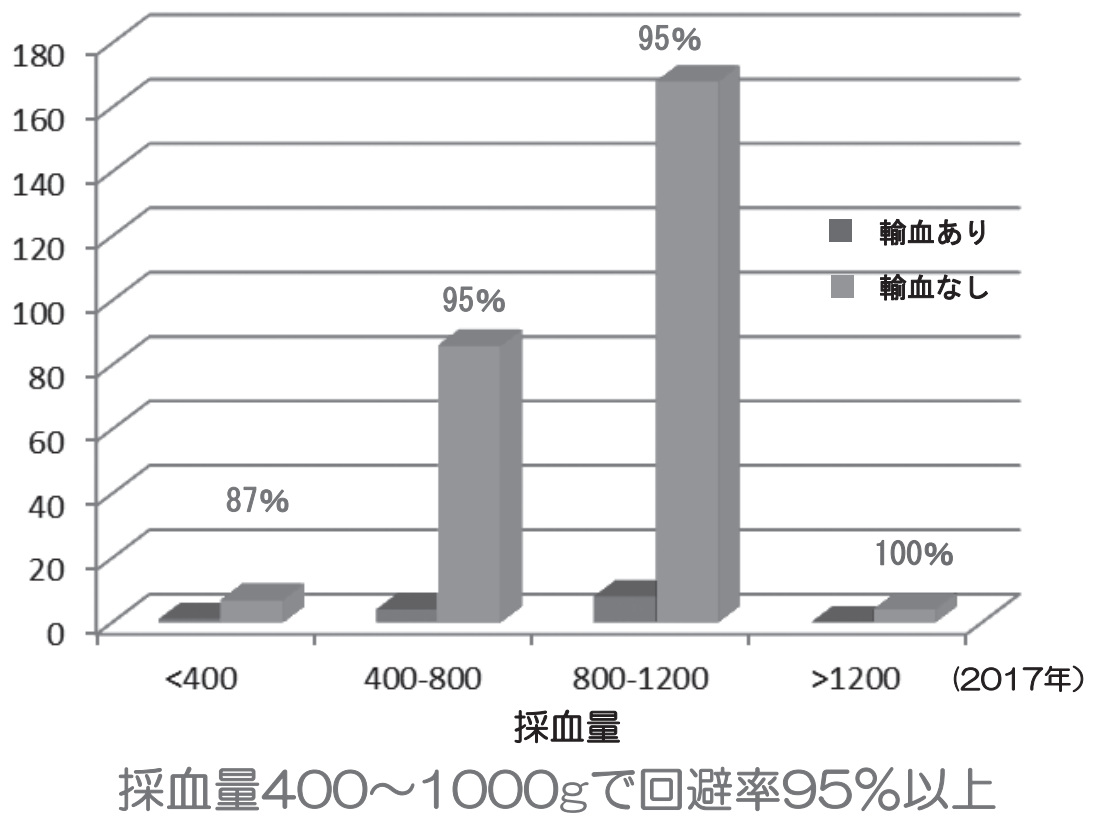

図3 同種血輸血の回避状況：採血量別

また手術の際に用いられる超音波凝固切開装置や 血管シーリングシステムなどのエネルギーデバイス の急速な進歩は，特に内視鏡手術の止血環境を向上 させただけでなく開腹手術でも使用されるようにな
つている ${ }^{10)}$ 。また， CT 三次元画像， ICG 蛍光，三 次元画像構築など画像診断技術の向上により正確で 安全な手術が可能となり，20～30年前の手術で生 じ得た “予想外の大量出血” は予定手術において今 


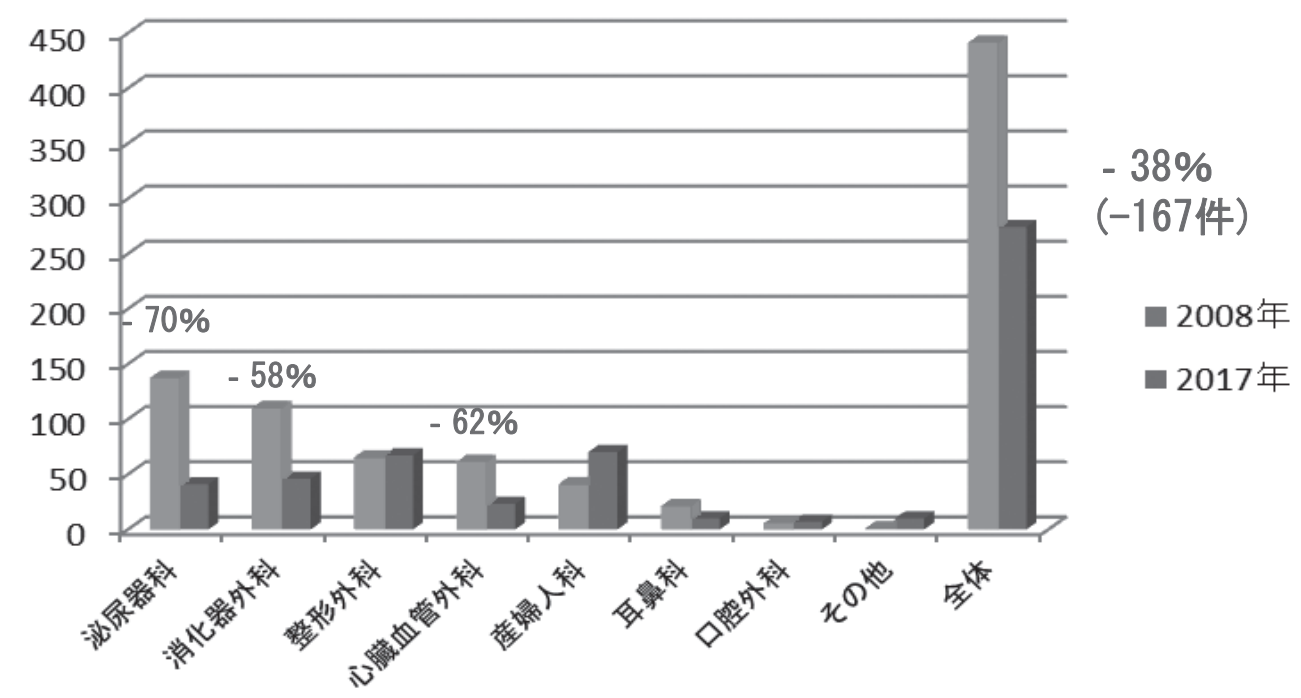

図4 診療科別：HAT症例の比較 (2008 年と 2017年の比較)

後は減少すると思われる。

\section{HATの今後の役割}

それではHATは不要な治療となるだろうか？ 同種血輸血の安全性が向上し HATを含む自己血輸 血の意義について論ずる向きもあるかもしれない. しかし前述したようにHATを含む自己血輸血の目 的は, 同種血輸血の回避による予後の改善と安全性 の向上である。したがって手術の低侵襲化や止血環 境の向上がさらに進むのであれば輸血治療も先進的 で質の高い手段に移行すべきであろう(図5)。新し い手術環境と止血環境では “輸血準備量”を増やす のでなく“HATを含む自己血輸血の運用”が第 1 選択となるかもしれない，当施設における “2,000g 以下の出血量で $87 \%$ の患者が同種血輸血を回避す る”結果は, 出血量が減少する時代に効率的で質の 高い輸血治療として認められ，2016年にHATの保 険収載が認められた。今後, 急速な普及が予想され るが，主治医だけでなく関連する部署(輸血部，手 術部看護師，臨床工学技士，検査技師など）との協 力体制を構築し, 貯血式や回収式との併用を考えて 患者に最も効率の良い輸血治療の選択をすべきであ

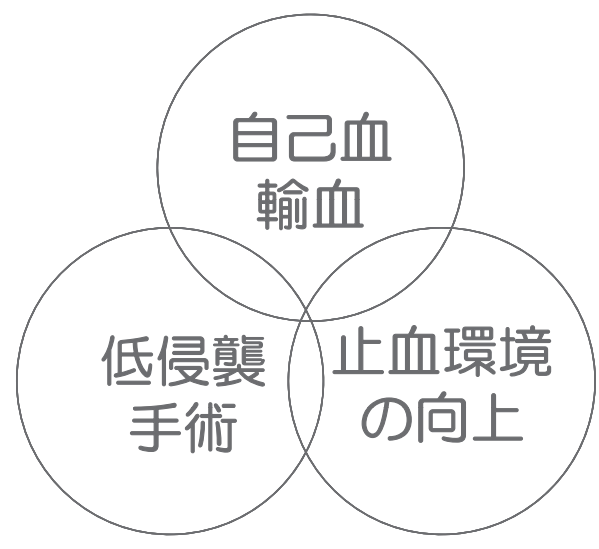

\section{出血の要因が減少し自己血の役割の増大}

图 5 予後の改善と安全性の向上

る，HATを含む自己血輸血の選択は，麻酔科医の 判断と技量により患者予後を改善しうる治療の一つ と考えている.

\section{まとめ}

当院におけるHATによる同種血輸血回避の取り 組みを紹介した。同種血輸血によるウイルス感染の 報告は激減したが，腫瘍免疫低下による再発予後へ 
の影響は否定されていない. 今後, 手術の低侵襲化 や止血環境の向上に伴い輸血治療も HAT を含む自 己血輸血が患者の予後を改善する大きな役割を担う と予想される。麻酔科医を中心に看護師, 輸血部の 協力体制による病院全体での効率的で安全な運用が 望ましい.

\section{参考文献}

1）輸血情報 1804-159 輸血用血液製剂の安全対策の導入効 果と輸血による HBV，HCV 及びHIV 感染のリスク，日 本赤十字社

2) 日本麻酔科学会・周術期管理チーム委員会編：周術期 管理チームテキスト(第 3 版). 社団法人日本麻酔科学会, 2016

3）廣田和美：輸血と免疫. 臨床麻酔 40：974-980, 2016

4) Bauer H, Pichlmaier H, Messmer K, et al. : Autotransfusion through acute, preoperative hemodilution --1st clinical experiences. Langenbecks Arch Chir (Suppl) : 185-189, 1974

5) Francis DM : Relationship between blood transfusion and tumour behaviour. Br J Surg $78: 1420-1428,1991$

6) 阿部力哉：輸血と癌. 日本外科系連合学会誌 $19: 8-15$, 1994

7) Chen G, Zhang FJ, Gong M, et al. : Effect of perioperative autologous versus allogeneic blood transfusion on the immune system in gastric cancer patients. J Zhejiang Univ Sci B $8: 560-565,2007$

8) Hiller J, Brodner G, Gottschalk A : Understanding clinical strategies that may impact tumour growth and metastatic spread at the time of cancer surgery. Best Pract Res Clin Anaesthesiol 27 : 427-439, 2013

9）玉井佳子, 田中一人, 伊藤悦朗ほか：貯血式自己血輸 血の有用性. 日本臨床麻醉学会誌 $33: 350-355,2013$

10) Fuchshuber PR, Robinson TN, Feldman LS, et al. : Fundamental Use of Surgical Energy (FUSE) : Closing a Gap in Medical Education. Ann Surg $262: 20-22,2015$ 


\title{
Utility of Hemodilutional Autologous Blood Transfusion to Avoid Allogeneic Blood-related Adverse Effects
}

\author{
Masato KITAYAMA*1, Junichi SAITO*2, Kazuyoshi HIROTA*2 \\ ${ }^{* 1}$ Operation Department, Hirosaki University Hospital \\ ${ }^{* 2}$ Department of Anesthesiology, Hirosaki University Graduate School of Medicine
}

Autologous blood is the best blood transfusion therapy for avoiding allogeneic blood transfusion-related adverse effects. The methods commonly used to obtain autologous blood during the perioperative period can be initiated prior to the operative procedure (autologous preoperative donation, hemodilutional autologous blood transfusion) or during surgery (cell scavenging). Hemodilutional autologous blood transfusion(HAT) involves the controlled removal of whole blood immediately prior to the operation and has many advantages including a lack of burdensome preparation, maintained coagulability and platelet function in the withdrawn blood, and usability even in patients with malignancy or infection. In addition, combining two or more methods can increase the probability of avoiding allogeneic blood transfusion-related complications. Since the 1990s, we have actively promoted the selection of HAT as the first choice for blood transfusion therapy in patients expected to experience a large amount of blood loss during scheduled surgery at our hospital. As of 2008, approximately $90 \%$ of surgical patients with hemorrhaging of $<2,000 \mathrm{~g}$ and $40 \%$ of patients with blood loss between 2,000 $\mathrm{g}$ and 3,000 $\mathrm{g}$ were able to avoid allogeneic blood use. The safety of allogeneic blood transfusion has improved dramatically in recent years, making it possible to avoid HCV, HBV and HIV infection, but transfusion-related acute lung injury still has a high mortality rate, and managing immunomodulation-related recurrence remains a challenge. Recent improvements in hemostasis as well as minimally invasive surgical techniques and high-functioning surgical energy devices may reduce or even eliminate the need for autologous blood transfusion including HAT in the future.

Key Words : Hemodilutional autologous blood transfusion, Allogeneic blood transfusion, Blood transfusion-related complications

The Journal of Japan Society for Clinical Anesthesia Vol.39 No.5, 2019 